\title{
BLOOD GROUP TYPES IN GREEKS FROM MAGNISIA AND LARISSA DISTRICTS (EASTERN THESSALY)
}

\author{
Magdalena Pirinska-Apostolou, Veneta Angelova \\ Department of Zoology and Anthropology, Faculty of Biology, Sofia University \\ "St. Kliment Ohridski", Bulgaria
}

\begin{abstract}
.
The study of the human ABO blood system is of high significance for the anthropological characterization of a population. For the aims of the present study there have been examined in view to ABO blood group system 237 individuals, as well as and 245 individuals according to Rh system - of both genders. The studied contingent represents a heterogeneous student group from eastern Thessaly Region, Central Greece. Among the sample blood group $0 \alpha \beta$ showed the highest frequency - 39,66\% whereas most rare was AB $(9.28 \%)$. Gender differences regarding the frequency of blood groups 0 and A were also established. $86.93 \%$ of individuals have positive $\mathrm{Rh}$ factor. Rh - positive is more frequent among women $-90.08 \%$, and Rh-negative in men (9.92\%). The comparison of the obtained genetic frequencies with older data showed heterogeneity among local Greek populations in comparison with some more distant ones. Accumulation of further data is needed, in order to solve the questions arisen.
\end{abstract}

Key words: $\quad$ physical anthropology, ABO blood group system, Rh - factor system, Greek students, Thessaly.

\section{Introduction}

The AB0 system was discovered in 1901, but since then many researchers are tried to find connections between blood group system and various aspects of anthropology and medicine (Maksimova et al., 2002; Maksimova et al., 2007; Timceva et al., 1998-1999; Todorov et al., 2004; Vizev et al., 1987); ethnicities, regions, races, population dynamics (Todorov et al., 1983; Todorov et al., 1991; Todorov et al., 1993; Todorov et al., 1996; Todorov et al., 1998-1999; Janeva et al., 2005; Torun et al., 2012; Özkasap et al., 2013; Nedjlaa 2013); life expectancy (Todorov 1981); paternity. The widespread use of serological systems makes them exactly relevant to the anthropological characteristics of a population (Bliznakov, Popvasilev, 1980). Although these characters have been well studied worldwide including Greece in total (Constantoulis, Paidousis, 1958; Xirotiris et al., 1980; Kremastinou, 1996; Lialiaris et al., 2011), or by administrative region (Paidousis, Krimbas 1980), there is no current information about the frequency distribution of the blood groups in this particular study area. Thanks to the contemporary human migration worldwide, as well as in the study area the native gene pool changes during time, and hence the frequency distribution of $\mathrm{AB} 0$ and $\mathrm{Rh}$ blood groups are also changing (Lialiaris et al., 2010).

The purpose of this study is to examine the genetic frequencies of blood groups AB0 and $\mathrm{Rh}$ system the native population of eastern Thessaly, as well as to compare them with nearby inhabiting groups on the basis of previous bibliographic sources.

Autor za korespondenciju: Magdalena Pirinska-Apostolou, e-mail: mpirinska@abv.bg

Department of Zoology and Anthropology, Faculty of Biology, Sofia University "St. Kliment Ohridski", Bulgaria

Primljeno u redakciju 22. 02. 2015, rad prihvaćen za publikovanje 11. 09. 2015. 


\section{Material and methods}

The current study was conducted in eastern Thessaly - Central Greece (cities Volos, Larisa and adjacent villages). The population inhabiting the study area represents about $70 \%$ of that in Thessaly region. 237 clinically healthy individuals of both genders (123 women and 114 men), as well as 245 individuals (131 women and 160 men) have been questioned about their blood group type and Rh- system respectively. The fact about every concrete blood group type was extracted from personal health books, preliminary tested in laboratory. The sample covers a diverse age group and has been studied in terms of their uncontamined origin up to three generations ago by questionnaire method. The genetic frequencies have been calculated from the experimental phenotypic AB0 types, under Hardy-Weinberg's law (1908). Differences between the experimental frequencies between male and female part of the examined sample have been estimated by the aims of Chi square test. The obtained results have been compared with the $\mathrm{AB} 0$ genetic frequencies of other populations, which inhabit nearby areas. Under this consequence, the examined group has been probably contemporary or during the past influenced by them. The divergence between the studied and other populations was estimated according to Nei, (1972). Visualization of the genetic distances between the populations has been accomplished according to Culman et al., 2009.

\section{Results}

The most frequent blood group type among the examined group occurred to be $0_{\alpha \beta}$ (39.66\%), as opposed to AB (9.28\%), which corresponds to the data of V. Todorov, 1986. Blood type A predominates among women, whereas 0 among men. Nevertheless, these differences according to gender are not statistically provable $\left(\kappa=3, x^{2}=2.71\right.$ and $\left.p>0.05\right)$.

Table 1. Established and expected genetic frequencies concerning the ABO blood type system in inhabitants of eastern Thessaly region, central Greece.

\begin{tabular}{|c|c|c|c|c|c|c|c|c|c|}
\hline \multirow[t]{2}{*}{ Gender } & & & \multicolumn{4}{|c|}{ Blood group type } & \multirow[t]{2}{*}{$\mathrm{p}$} & \multirow[t]{2}{*}{$\mathrm{q}$} & \multirow[t]{2}{*}{$\mathrm{r}$} \\
\hline & & & $\mathrm{O}$ & $\mathrm{A}$ & $\mathrm{B}$ & $\mathrm{AB}$ & & & \\
\hline \multirow[t]{2}{*}{ Males } & $\mathrm{n}=144$ & $\mathrm{n}$ & 51 & 35 & 17 & 11 & & & \\
\hline & & $\%$ & 44.74 & 30.7 & 14.91 & 9.56 & & & \\
\hline \multirow[t]{2}{*}{ Females } & $\mathrm{n}=123$ & $\mathrm{n}$ & 43 & 46 & 23 & 11 & & & \\
\hline & & $\%$ & 34.96 & 37.4 & 18.7 & 8.94 & & & \\
\hline \multirow[t]{2}{*}{ Total -established } & $\mathrm{n}=237$ & $\mathrm{n}$ & 94 & 81 & 40 & 22 & & & \\
\hline & & $\%$ & 39.66 & 34.18 & 16.88 & 9.28 & 0.248 & 0.140 & 0.612 \\
\hline Total -expected & $\%$ & & 37.36 & 36.48 & 19.18 & 6.98 & 0.247 & 0.140 & 0.613 \\
\hline
\end{tabular}

The expected and experimental genetic frequencies are almost the same, which is an indication for genetic equilibrium. $\mathrm{p}$ is also of lower frequency, compared to $\mathrm{q}$.

In terms to Rhesus factor, $86 \%$ of the examined individuals are positive. More women have positive Rhesus factor, in comparison to men (90.08\% and $82.46 \%$ respectively) and the opposite (table 2). These differences are not statistically significant $\left(\kappa=1, \mathrm{x}^{2}=3.03\right.$ and $\left.\mathrm{p}>0.05\right)$.

Calculation of the theoretical and the observed genetic frequencies showed that they are approximately the same. The derived results concerning the frequency of Rhesus factor correspond to the specific for the total European population frequencies (Шаповалова, 1962). 
Table 2. Established and expected genetic frequencies concerning the Rh blood type system in inhabitants of eastern Thessaly region, central Greece.

\begin{tabular}{|c|c|c|c|c|c|}
\hline \multirow[t]{2}{*}{ Gender } & & \multicolumn{2}{|c|}{ Rh system } & \multirow[t]{2}{*}{$\mathrm{p}$} & \multirow{2}{*}{$\mathrm{q}$} \\
\hline & & $(+)$ & $(-)$ & & \\
\hline \multirow{2}{*}{ Males } & $\mathrm{n}=114 \mathrm{n}$ & 94 & 20 & & \\
\hline & $\%$ & 82,46 & 17,54 & & \\
\hline \multirow[t]{2}{*}{ Females } & $\mathrm{n}=131 \mathrm{n}$ & 118 & 13 & & \\
\hline & $\%$ & 90,08 & 9.92 & & \\
\hline \multirow[t]{2}{*}{ Total - established } & $\mathrm{n}=245 \mathrm{n}$ & 212 & 33 & & \\
\hline & $\%$ & 86,53 & 13,47 & 0.633 & 0.367 \\
\hline Total - expected & $\%$ & 86,53 & 13,47 & 0.633 & 0.367 \\
\hline
\end{tabular}

\section{Discussion}

Similar expected and experimental genetic frequencies of Blood groups and Rhesus factor are indicator for a Hardy-Weinberg's equilibrium. This result derives from the fact of the sample's uncontamined origin.

In view to the established genetic frequencies of the $\mathrm{AB} 0$ blood groups system and compared with previous studies given in table 3, the examined sample is most divergent compared to the inhabitants of Odrin town (DNei=0.008) and most akin to these from Romania (DNei=0.001). When compared with the frequencies established before for Greek population in total (table 4), a slightly increased $q$ on account of $r$ is established, whereas $p$ remains inside the range.

Table 3. Various groups compared to a population from Eastern Thessaly, central Greece on the basis of their of their AB0 blood groups genetic frequencies.

\begin{tabular}{lll}
\hline Origin & & \\
\hline Volos+Larissa & & \\
Eastern Thessaly - Greece & V+L-GR & current study \\
Iraklion Greece & Ira-GR & Paidousis, Krimbas, 1980 \\
Rhodos Greece & Rho-GR & Paidousis, Krimbas, 1980 \\
Karditsa Greece & Kat-GR & Paidousis, Krimbas, 1980 \\
Atalandi Greece & Ata-GR & Paidousis, Krimbas, 1980 \\
Halkidiki Greece & Hal-GR & Paidousis, Krimbas, 1980 \\
Total Bulgaria & Tot-BG & Popov et.al, 2012 \\
Total Turkey & Tot-TR & Akbay et al., 1989 \\
Odrin/Edirne/Adrianoupolis Turkey & Odr-TR & Çobancik, 1998 \\
Total Cyprus & Tot-CY & Atun et al. \\
Total Albania & Tot-AL & http://www.bloodbook.com/world-abo.html \\
Total Italy & Tot-IT & http://www.bloodbook.com/world-abo.html \\
Total Serbia & Tot-SR & http://www.bloodbook.com/world-abo.html \\
Total Romania & Tot-RO & http://www.bloodbook.com/world-abo.html \\
\hline
\end{tabular}

These data seem controversial, but two circumstances have to be taken into account:

-The comparison has been accomplished on the basis of only one locus.

-The examined sample is of proved uncontamined origin. The data used for comparison from other sources are described from "inhabitants" of given area, but not "proved native population". 
Nevertheless, if we accept that the heterogeneity of origin concerning some of the samples studied before is not affecting frequencies, heterogeneity of $\mathrm{AB} 0$ genetic frequencies among local groups in Greek territory cannot be excluded. AB0 system alone probably does not represent a good distinguishing genetic marker for some neighbor human populations - in this case a perquisite for Hardy-Weinberg's equilibrium is lacking: migration is constant in the region from about $4000 \mathrm{BC}$.

Accumulation of further data obtained on the basis of various genetic markers and other methods is needed in local scale, in order to solve the questions arisen.

Table 4. Genetic frequencies of $A B O$ Blood group system in Greece according to various sources and current study.

\begin{tabular}{lccc}
\hline Genetic frequences & $\mathrm{p}$ & $\mathrm{q}$ & $\mathrm{r}$ \\
\hline Constantoulis, Paidousis, 1958 (Greeks, total) & 0.246 & 0.094 & 0.661 \\
Xirotitis, 1980 (Pomacs) & 0,265 & 0.068 & 0.668 \\
Paidousis, Krimbas, 1980 (Greeks, total) & 0.266 & 0.098 & 0.636 \\
Kremastinou, 1996 (Greeks, total) & 0.266 & 0.110 & 0.624 \\
Lialiaris, 2010 (Greeks, total) & 0.260 & 0.114 & 0.625 \\
Current study (eastern Thessalians) & $\mathbf{0 . 2 4 8}$ & $\mathbf{0 . 1 4 0}$ & $\mathbf{0 . 6 1 2}$ \\
\hline
\end{tabular}

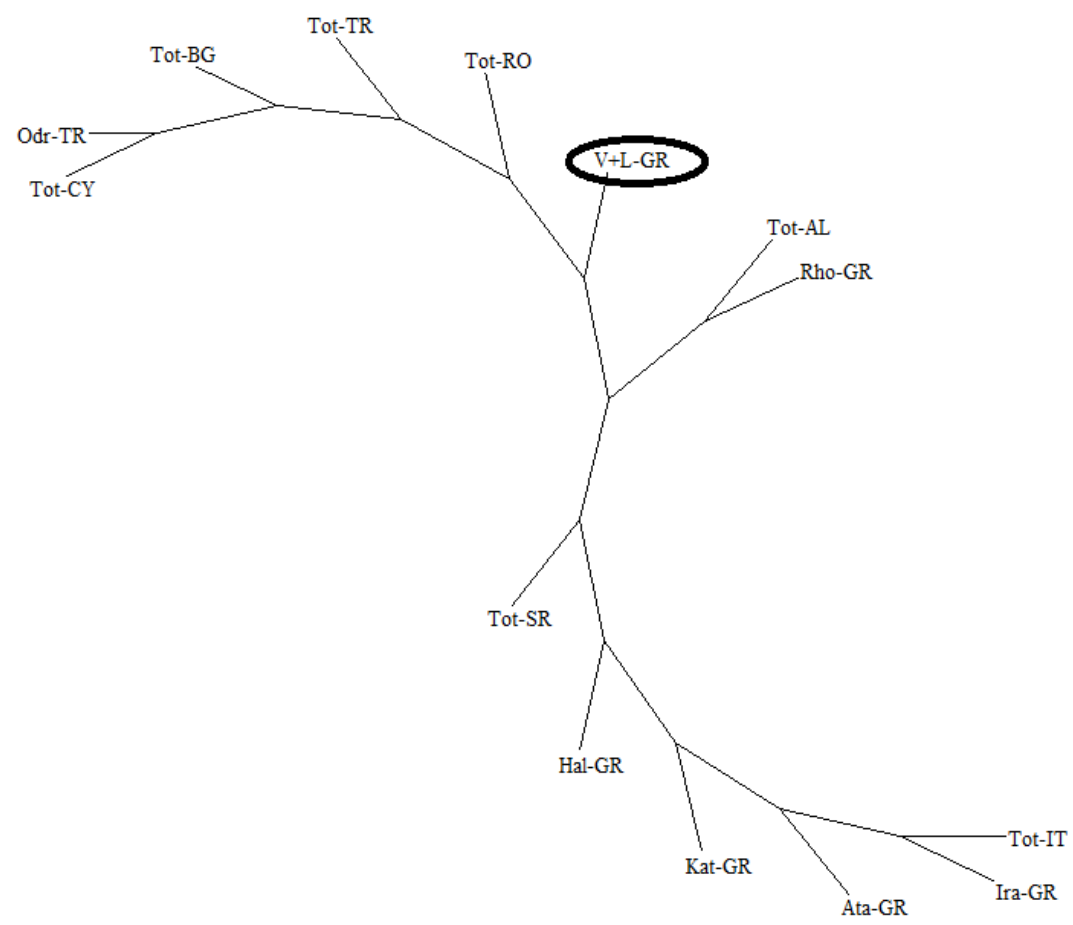

Figure 1. Nei's (1972) genetic distances calculated on the AB0 genetic frequencies between a studied population from eastern Thessaly region, central Greece, and nearby inhabiting groups. Abbreviations are given in table 3 . 


\section{References}

Близнаков, Хр. И. Попвасилев. Кръвногрупови системи у човека. Мед. и физк. София. 1980.

Попов Р., Н. Петров, В. Васева. Разпространение на кръвните групи от системата АВ0 при имунохематологичната диагностика във ВМА. Български медицински журнал. 2012, VI 2, 45-48.

Шаповалова, М. Я. Новые данные по распределению групп крови $\mathrm{ABO}, \mathrm{MN}$ и $\mathrm{Ph}$ среди населения Европы. Вопр. антр. 1962; 91, 100-114.

Akbay T, Demiröz P, Güney Ç, et al. Türkiye'de kan gruplarının coğrafi bölgelere göre dağılımı. GATA Bült. 1989; 31: 391-402.

Atun IH, Hacıbulgur M. Kıbrıs. Türklerinde ve komşu ülkelerde kan grupları. Mikrobiyoloji Bülteni. $1979 ; 13: 173$

Çobancık N. Trakya yöresinde ABO ve Rh kan gruplarının dağılımı ve genetik analizleri. Yüksek Lisans Tezi. Trakya Üniversitesi Fen Bilimleri Enstitüsü. 1998: 40-5.

Constantoulis, N.C., M. Paidoussis. The distribution of ABO, MNS and Rh blood groups in Greece. Vox Sanguinis. 1958; 3, 145.

Culman, S.W., Bukowski, R., Gauch, H.G., Cadillo-Quiroz, H., Buckley, D.H. T-REX: Software for the Processing and Analysis of T-RFLP data. BMC Bioinformatics. 2009; 10: 171

Janeva E., R.Stoev, L.Kavgazova. Comparative population-genetic analysis of ABO and Rh blood group factors in the population from Zlatograd region (South-East Bulgaria). Proceedings of the Balkan scientific conference of biology in Plovdiv (Bulgaria) from 19th till 21st of May 2005; (72-85)

Kremastinou, J., G. Tzanakaki, P. H. Karafoti, R. A. Elton, D. M. Weir, C. C. Blackwell. Distribution of ABO and Lewis blood groups in Greece. Gene Geography. 1996; 10, 201.

Lialiaris T., E. Digkas, D. Kareli, S. Pouliliou, B. Asimakopoulos, O. Pagonopoulou, M. Simopoulou. Distribution of $\mathrm{ABO}$ and $\mathrm{Rh}$ blood groups in Greece: an update. International Journal of Immunogenetics. 2010; 38(1): 1-5.

Maksimova, S., V. Todorov, A. Tomova. Pripadnost krivnim grupama iz sistema ABO I Rezus faktor i kardio-vaskularna obolenja. Glasnik ADJ. 2002; sv. 374: 271-275

Maksimova, S., V. Todorov, V. Hristova. Karcinom na želucu kao deo neoplazme probave. Glasnik ADJ. 2007; sv. 42, 35-37.

Mortad Nedjlaa. Anthropogenetic characterization of the population of Msirda based on the polymorphism of blood groups ABO, Rhesus, and Duffy MNSs across the Mediterranean. Annals of Biological Research. 2013; 4 (8): 101-111

Nei, M. (1972). "Genetic distance between populations". Am. Nat. 106: 283-292.

Paidousis, M., C. B. Krimbas. The distribution of $\mathrm{ABO}$ and $\mathrm{Rh}$ blood groups in Greece. In: Schwidetzky, I., B. Chiarelli, O. Necrasov (Eds). Physical anthropology of European populations, Hague-Paris-New York,MoutonPubl. 1980; 145-170.

Serdar Özkasap, Selim Dereci, Kazım Şahin, A. Ramazan Dilek, Erdin Kalyoncuoğlu, Tuğba Zengin, Banu Özata. Analysis of $\mathrm{ABO}$ and $\mathrm{Rh}$ blood groups distribution in East Karadeniz region of Turkey. Dicle Medical Journal. 2013; 40 (1): 100-104

Timceva, A., S. Maksimova, V. Todorov. Raspodela krvnih grupa ABO I rezus factor kod pacijenata sa cirozom jetre i hroničnim hepatisisom. Glasnik ADJ. 1998-1999; sv. 34, $203-207$.

Todorov, V.. Krvne grupe osobe iznad 60 godina starosti. Glasnik ADJ. 1981; sv. 18, 199-203.

Todorov, V., K. Jordanova, Tz. Liposhlieva. Bloodgroup characterization of two ethnical groups in Bulgaria. God. sb. Med. Fak, Skopje. 1983; 29(2), 177-178.

Todorov, V., M. Rubljova. Karakteristika krvnih grupa Grka i Armenaca. Posebno izdanje Glasnik ADJ. 1986 sv. 9, 11-116.

Todorov, V., G. Bozikova, M. Kicheva. Bloodgroope belong in to ABO and Rhezus systeme of two ethnic groups. First national conference of Anthropology with international partipation, Plovdiv. 1991; 183-189.

Todorov, V., S, Maximova, M. Radkova. Sistemi krvnih grupa ABO i rezus faktor kod dve narodnosti sa različitom etnogenezom. Glasnik ADJ. 1993; sv. 29, 83-86.

Todorov, V., V. Daskalova, S. Maximova. Karakteristika krvnih grupa kod stanovništva Deninskog regiona. Glasnik ADJ. 1996; sv. 32, 29-32. 
Todorov, V., S. Maksimova, V. Angelova. Sistemi krvnih grupa ABO i Rezus factor kod raznih etničkih grupa koje žive u Bugarskoj. Glasnik ADJ. 1998-1999; sv. 34, 209-213.

Todorov, V., S. Maksimova, V. Hristova. Krvnogrupna pripadnost sistemima ABO i Rezus faktor kod pacijenata sa apendektomijom. Glasnik ADJ. 2004 sv. 39, 83-86.

Villa A., F. Drago, R. Mistò, F. Morelati, F. Poli, G. Sirchia. AB0 genotyping in Italian blood donors. Haematologica. 1996; 81: 492-496

Vizev, St., V. Todorov. ABO krvnogrupni sistem kao faktor rizika za razvoj ateroskleroze. Poselno izdanje Glasnik ADJ. 1987; sv.9, 117-123.

Xirotiris, N. Serological studies of the Pomacs. In: Schwidetzky, I., B. Chiarelli, O. Necrasov (Eds). Physical anthropology of European populations, Hague-Paris-New York,MoutonPubl. 1980; 239-241.

Yasemin Altuner Torun, Leyla Gül Kaynar, Cigdem Karakükcü, Mehmet Yay, Fatih Kurnaz, Hasan Mutlu, Mustafa Cetin, Bülent Eser. ABO and Rh Blood Group Distribution in Kayseri Province, Turkey. Turkish Journal of Haematology. 2012; 29(1): 97-98.

http://www.bloodbook.com/world-abo.html. Last accessed 17.05.2014.

\title{
TIPOVI KRVNIH GRUPA KOD GRKA U OKRUZIMA MAGNEZIJA I LARISA (ISTOČNA TESALIJA)
}

\author{
Magdalena Pirinska-Apostolou, Veneta Angelova
}

\begin{abstract}
Apstrakt. Studija ABO sistema krvnih grupa veoma je značajna za antropološku analizu date populacije. U ovoj studiji, uzorkom je obuhvaćeno 237 osoba radi ispitivanja ABO sistema krvnih grupa i 245 osoba radi ispitivanja $\mathrm{Rh}$ sistema, kod oba pola. Ispitanici predstavljaju heterogenu grupu studenata iz oblasti istočne Tesalije u centralnoj Grčkoj. Najčešće zastupljena krvna grupa je 0aß - 39,66\%, dok je najmanje zastupljena AB krvna grupa (9.28 $\%$ ). Ustanovljene su razlike zastupljenosti krvnih grupa 0 i A u pogledu pola. $86.93 \%$ osoba ima pozitivan Rh faktor. Veći broj žena je Rh-pozitivno - 90.08\%, dok je kod muškaraca veći broj Rh-negativan (9.92\%). Upoređivanje dobijenih podataka sa ranijim podacima ukazuje na razlike između lokalne grčke populacije i nekih drugih populacija. Potrebno je prikupiti dodatne podatke kako bi se odgovorilo na pitanja koja se ovde nameću.
\end{abstract}

Ključne reči: fizička antropologija, ABO sistem krvnih grupa, Rh sistem, grčki studenti, Tesalija. 